\title{
The Social Union after the Coalition: Devolution, Divergence and Convergence
}

\author{
MARK SIMPSON \\ School of Law, Ulster University, Northland Road, Derry/Londonderry BT48 7JL, UK \\ email:m.simpson@ulster.ac.uk
}

\begin{abstract}
In 2009, the UK government emphasised that it was 'deeply committed' to the maintenance of the state's social union, embodied in a single social security system. Five years later, the future of this social union appeared less certain than at any time since the 1920s. Dissatisfaction with the 'welfare reform' agenda of the coalition government was a driver of support for Scottish independence in the 2014 referendum campaign. Meanwhile, the Northern Ireland Assembly failed to pass legislation to mirror the Welfare Reform Act 2012, normally a formality due to the convention of parity in social security. Despite Westminster's subsequent extension of the 2012 reforms to the region, divergence in secondary legislation and practice remains likely. This article draws on the findings of qualitative interviews with politicians and civil servants in both regions during a period covering the conclusion of the Smith Commission's work on the future of Scottish devolution and the height of a political impasse over Northern Ireland's Welfare Reform Bill that threatened a constitutional crisis. It considers the extent to which steps towards divergence in the two devolved regions have altered the UK's social union and to which the two processes have influenced one another.
\end{abstract}

\section{Introduction}

The Conservative-Liberal Democrat coalition's social security reforms formed a milestone in the evolution of social citizenship in the UK, further advancing a trend whereby access to a minimum standard of living is increasingly contingent on labour market participation. Meanwhile, the hostile devolved-level reaction to UK government policy points to the continuation of a process ongoing since 1998, whereby the manner in which the social rights of citizenship are realised, and perhaps the nature of those rights, varies between regions. The 2014 referendum on Scottish independence was a high-profile manifestation of the latter; questions of citizens' welfare and disquiet with the welfare reform agenda featured prominently in secessionist rhetoric (Mooney and Scott, 2015). Following voters' rejection of independence, the UK government has begun to act on commitments to devolve additional powers in fields including 'welfare' (Clegg, 2014). Meanwhile, concerns about Westminster policy in Northern Ireland have underpinned the most serious challenge yet to the parity convention, under which 
that region, despite devolved competence for social security, imitates provision in Great Britain.

This article explores changes to the social union following the Welfare Reform Act 2012, building on regionalisation of social citizenship since 1998. Section 1 outlines the position of social security as a rare field of social policy relatively unaffected by devolution and identifies the 2012 Act as a turning point. Section 2 then examines the extent to which reactions to coalition policy in Scotland and Northern Ireland, and the resulting changes to the devolution settlement, have been mutually influential or driven by region-specific considerations, as well as the continued ability of the UK government to shape devolved-level policy. Section 3 asks whether the drive for greater autonomy results as much from 'welfare nationalism' as from objections to the 2012 reforms, before section 4 emphasises the continued uncertainty regarding the future shape of the social union.

The study on which the article draws explores the attitudes of key members of the policy community in two devolved regions to social citizenship and social security at a critical point in the development of the devolution settlement. Thirtysix politicians and civil servants, drawn from the five main political parties in the two legislatures and from government departments or directorates with an interest in social security, citizens' welfare or finance, took part in semi-structured interviews. Individuals with knowledge of relevant issues, and who might be expected to play a role in decision-making on the future locus of competence for social security and subsequent policy, were targeted. Nineteen interviewees came from Northern Ireland and 17 from Scotland; 18 were politicians of whom 8 represented pro-union parties, 8 represented nationalist/secessionist parties and 1 a party neutral on the constitutional issue; 18 were civil servants. Fieldwork was completed between November 2014 and February 2015, coinciding with talks in Northern Ireland that briefly promised to allow the region's Welfare Reform Bill to complete a legislative journey stalled since February 2013 (Northern Ireland Office (NIO), 2014) and publication of the proposals for the future of Scottish devolution. Data analysis was guided by grounded methods (Glaser and Strauss, 1967; Charmaz, 2006).

\section{Social citizenship, the social union and devolution}

Social citizenship refers to the citizen's right to a minimum standard of living, the state's obligation to fulfil 'normative expectations about how the basic requirements of ... personal welfare and development can be met' (Harris, 2013: 4). Marshall, who coined the term, is commonly associated with a national view of citizenship, wherein responsibility for the definition and realisation of the individual's civil, political and social rights lies with the nation state (Mooney and Williams, 2006; Keating, 2009). If social rights were to be 'exercised by all 
citizens equally', it followed that they should be national in application and realised with a high degree of uniformity by a national welfare state (McLean et al., 2013: 107). Wincott (2006) argues that in the UK a perfectly unitary welfare state never existed in reality and such a perspective appears particularly dated in an era of multi-level governance, when social entitlements are defined and realised at 'different territorial scales' (Lodge and Trench, 2014: 10) - the state, supranational bodies and subnational territories (Faist, 2001).

Devolution has impacted upon the social rights of citizenship: devolved functions are so dominated by social policy competences that the regional legislatures have been characterised as 'social policy parliament[s]' (Birrell, 2009: 13; 2010). There is some evidence that regional differences in electorates' social policy preferences are limited (Curtice and Ormston, 2011; Henderson et al., 2013; Mitchell, 2014). However, political elites' policy preferences may nonetheless differ from those of the UK government - and devolution provides an opportunity to pass distinctive regional legislation where this is the case. Post-1998 divergence (see Birrell, 2010) is claimed to have produced 'a particularly Scottish [or Welsh, or Northern Irish] welfare state' (Mooney and Poole, 2004: 477). Whether this results from innovation at regional level or 'refusal to pursue some of the UK government's more radical policy initiatives' (McEwen, 2005) varies from case to case.

Social security stands as an exception. Competence is reserved to the UK government for all of Great Britain (Scotland Act 1998 sch 5 head F; Government of Wales Act 2006 sch 5), although centralisation is being eroded (Social Security Advisory Committee (SSAC), 2015; Scotland Act 2016: part 3). In Northern Ireland, devolved competence since 1921 has resulted in almost no deviation from policy in Great Britain. Devolved governments anxious to 'preserve the same standard of living... as prevails on the other side' of the Irish Sea (Craig, 1925) have, with minor exceptions, provided identical cash benefits under near-identical conditions (Simpson, 2015). This practice - the parity convention - has been financially supported by the UK government since 1926 , by which stage provision of equivalent social protection from regional revenues had become unsustainable in what remains an economically weaker region (Lawrence, 1965). Today, the Treasury subsidises contributory benefits and fully funds non-contributory benefits in Northern Ireland outside the block grant from which other devolved services are funded, at a cost of $\mathfrak{L}_{3} .2$ billion in 2012-13 (HM Revenue and Customs, 2013; Department for Social Development, 2013). Although constitutional legislation merely requires the relevant Northern Ireland Minister to 'consult' the Secretary of State 'with a view to securing that, to the extent agreed between them, the legislation... provides single systems of social security, child support and pensions for the United Kingdom' (Northern Ireland Act 1998: s87(1) - emphasis added), prior to 2012 uniformity remained all but absolute, with parity seen to serve Northern Ireland's financial interests (Birrell and Gray, 2014). 
Events since 2012 have shaken the status quo. The 2010-2015 coalition government combined an ongoing project to cast paid employment as the primary route to economic security and jobseeking as the key manifestation of reciprocity in the welfare state (Larkin, 2011) with a new drive to reduce welfare spending (Stephens, 2015). Jobseeking conditionality for claimants was deepened and widened, financial sanctions for non-compliance stiffened, generosity of outof-work benefits cut, in-work support for some claimants increased and various social assistance benefits replaced with a single universal credit. The main disability benefit, disability living allowance, is being replaced by personal independence payment, less generous to many and for which at least 20 per cent fewer people are projected to be eligible (Harris, 2014). Despite its statement (under a previous administration) following the report of the Commission on Scottish Devolution (2009) that it remained 'deeply committed' to common social security provision as integral to the social union (Scotland Office, 2009: 4), the UK government has also withdrawn from discretionary welfare and council tax support, transferring responsibility to local and regional governments (SSAC, 2015).

Parties represented in devolved governments have been among the most vocal critics of the 'catastrophic' coalition agenda (Scottish National Party, 2013). Proposals for social security in an independent Scotland included specific short-term departures from UK policy and a long-term vision for a radically different welfare state (Expert Working Group, 2014). Following the prominence of questions of welfare in a broad sense as well as the narrower issue of welfare reform in the referendum campaign, plans were published for devolved control of disability benefits and aspects of universal credit (HMG, 2015; Scotland Bill). While devolution of power does not guarantee divergence will follow, the Scottish government will for the first time have the opportunity to adopt distinctive policies in some areas.

Northern Ireland's devolved competence for social security means politicians there are not limited to expressing their disapproval with UK government policy; the previous practice of swiftly replicating Westminster legislation was not followed for the 2012 Act. Although an equivalent Bill was introduced to the Assembly in October 2012, following a critical report by the Committee for Social Development (2013) the Executive parties were unable to agree the extent to which Northern Ireland should diverge from the legislation for Great Britain, resulting in the defeat of the Bill in May 2015 (Hansard, 2015). Following this apparent abandonment of parity, primary legislation would be swiftly and substantially brought back into line with Great Britain through the short-term transfer of social security competences to Westminster (Northern Ireland (Welfare Reform) Act 2015 C34; Welfare Reform (Northern Ireland) Order 2015). Nonetheless, previously agreed points of divergence have not disappeared. The 2015 Order provides for a shorter maximum sanction period than in Great Britain, changes to the payment arrangements for universal credit can be expected and the Executive will fund 
a four-year disapplication of the housing benefit size criteria for social tenants ('bedroom tax') (NIO, 2015). A Welfare Reform Mitigations Working Group (2016) was also appointed to consider further departures from UK government policy. It recommends supplementary payments to claimants who lose money due to various reforms. Since these are largely limited to one year, the extent to which recent reluctance to import wholesale reforms made at Westminster sets a new precedent for social security policymaking remains to be seen.

\section{Policy learning or innovation? Drivers of divergence and convergence}

Decentralisation of political power provides the opportunity for divergence in fields of devolved competence. However, if policy experiments in regional 'laboratories of democracy' (Keating and Cairney, 2012: 239) are deemed successful, they may be imitated in other regions (Birrell, 2010), as with the implementation of social assistance schemes across Spain's autonomous communities following experiments in Navarre and the Basque Country in the 1980 s (Arriba and Moreno, 2005). Criticism of UK government welfare reform policy in Scotland and Northern Ireland was followed by the publication of proposals for regional divergence in Northern Ireland (Storey, 2014) and the devolution of a new set of powers to Scotland that would allow it to make many similar changes, especially in respect of universal credit (see Table). This may reflect policy learning between the two regions (see Rose, 2000). In asymmetric devolution settlements, desire to copy a given policy, or simply to 'keep up' with one's neighbours, may also drive demand for additional delegated powers (Hombrado Martos, 2008). This clearly applies to Scotland, where significant divergence from UK government social security policy requires new devolved competences.

Sufficient similarity exists in the new social security competences to be devolved to Scotland and the divergences from UK government policy proposed in Northern Ireland to raise the question of whether the two regions have consciously learned from one another. For Dolowitz et al. (1999), genuine policy transfer requires engagement between policymakers for an exchange of ideas in the relevant policy field, resulting in the adoption in one (or each) jurisdiction of policies originating in the other. Opportunities for such exchanges certainly exist between Scotland and Northern Ireland, despite the absence from the latter of UK-wide political parties, sometime agents of policy learning in Scotland and Wales (Keating et al., 2012). Notably, the Smith Commission (2014) heard evidence on Northern Ireland's experiences of social security devolution. Among the participants, many civil servants were in contact with their counterparts across the North Channel, some politicians had taken part in British-Irish intergovernmental structures while many others reported informal contacts with 
TABLE. Comparison of recommended 'mitigations' in Northern Ireland with new powers in Scotland

\begin{tabular}{|c|c|c|c|}
\hline Benefit & $\begin{array}{l}\text { UK government } \\
\text { policy }\end{array}$ & NI proposal & $\begin{array}{l}\text { Future Scottish } \\
\text { competence }\end{array}$ \\
\hline Housing benefit & $\begin{array}{l}\text { Reduction for } \\
\text { under-occupation } \\
\text { (social tenants) }\end{array}$ & $\begin{array}{l}\text { Deferred for four } \\
\text { years }\end{array}$ & $\begin{array}{l}\text { Full control of } \\
\text { universal credit } \\
\text { housing element }\end{array}$ \\
\hline \multirow[t]{5}{*}{ Universal credit } & $\begin{array}{l}\text { Single household } \\
\text { payment }\end{array}$ & $\begin{array}{l}\text { Payments may be } \\
\text { split }\end{array}$ & $\begin{array}{l}\text { Power to vary single } \\
\text { household } \\
\text { payment }\end{array}$ \\
\hline & $\begin{array}{l}\text { Payment of housing } \\
\text { element to } \\
\text { claimants }\end{array}$ & $\begin{array}{l}\text { Direct payment } \\
\text { to landlords }\end{array}$ & $\begin{array}{l}\text { Power to pay } \\
\text { housing element } \\
\text { to landlords }\end{array}$ \\
\hline & Monthly payments & $\begin{array}{l}\text { Fortnightly } \\
\text { payments }\end{array}$ & $\begin{array}{l}\text { Power to vary } \\
\text { payment } \\
\text { frequency }\end{array}$ \\
\hline & $\begin{array}{l}\text { Maximum sanction } \\
\text { period three years }\end{array}$ & $\begin{array}{l}\text { Maximum } \\
\text { sanction } \\
\text { period } 18 \\
\text { months }\end{array}$ & $\begin{array}{l}\text { No competence for } \\
\text { conditionality }\end{array}$ \\
\hline & $\begin{array}{l}\text { Severe disability } \\
\text { premium } \\
\text { abolished }\end{array}$ & $\begin{array}{l}\text { One year } \\
\text { compensation }\end{array}$ & $\begin{array}{l}\text { No competence for } \\
\text { rates of benefit }\end{array}$ \\
\hline $\begin{array}{l}\text { Employment and } \\
\text { support allowance }\end{array}$ & $\begin{array}{l}\text { Contributory ESA } \\
\text { limited to one } \\
\text { year }\end{array}$ & $\begin{array}{l}\text { One year } \\
\text { compensation }\end{array}$ & $\begin{array}{l}\text { No competence for } \\
\text { ESA }\end{array}$ \\
\hline $\begin{array}{l}\text { All income } \\
\text { replacement benefits }\end{array}$ & $\begin{array}{l}\text { Cap on household } \\
\text { benefit income }\end{array}$ & $\begin{array}{l}\text { Four years } \\
\text { compensation } \\
\text { to claimants } \\
\text { with children }\end{array}$ & $\begin{array}{l}\text { Any new devolved } \\
\text { benefits outside } \\
\text { scope of cap }\end{array}$ \\
\hline Disability benefits & $\begin{array}{l}\text { Disability Living } \\
\text { Allowance } \\
\text { replaced with } \\
\text { Personal } \\
\text { Independence } \\
\text { Payment }\end{array}$ & $\begin{array}{l}\text { One year } \\
\text { compensation } \\
\text { for loss of } \\
\text { DLA/carer's } \\
\text { allowance } \\
\text { income }\end{array}$ & $\begin{array}{r}\text { Full competence for } \\
\text { disability benefits }\end{array}$ \\
\hline
\end{tabular}

Sources: HM Government (2015); NIO (2015); Welfare Reform Mitigations Working Group (2016)

their fellow parliamentarians. However, Northern Irish interviewees reported more contact with the UK government on social security matters than with the Scottish government.

Northern Irish interviewees were particularly likely to conclude that policy learning had been a feature of opposition to the welfare reform agenda there and in Scotland. Despite the constraints imposed by traditional adherence to parity and economic dependence, Northern Ireland was almost universally claimed to be building a better approach to social security than the UK government. Hence some interviewees there considered Scottish policymakers 'would give their eye teeth for the kind of flexibilities we've got' (civil servant, NI); about half felt 
their Scottish counterparts look to Northern Ireland as a role model as they contemplate use of their new powers. Proposals for further devolved powers, therefore, had been directly influenced by recognition that 'there were aspects of the Northern Ireland package of measures which would give Scotland a great deal of flexibility' (civil servant, NI). In Scotland, appetite to learn from Northern Ireland's experience of social security devolution was widespread - three quarters of the interviewees said they had taken a keen interest in events at Stormont and most of the remainder felt they would benefit from greater knowledge. However, the lesson learned tended to be how not to do things. Even a politician who considered the then-proposed 'tweaks' to Northern Ireland's Welfare Reform Bill to be 'very sensible' believed 'we need something rather more than that.' Other MSPs were more forthright in their view that 'things aren't working too well in Northern Ireland', which had found itself in a 'trap of it appearing that you have power over these things, but if you don't do what you're told it ends up costing you a lot of money.' So while Scottish interviewees were interested observers of Northern Ireland, a civil servant's suggestion that 'Scotland would see itself as very much out on its own, breaking the ice' rather than following in the footsteps of the smaller region may have been well founded.

If views as to Northern Ireland's influence on Scotland were mixed, about half of the Northern Irish interviewees pointed to learning in the opposite direction. For some the Scottish influence was felt on wider questions about the division of competences in the devolution settlement, the referendum having acted as 'a great eye-opener ... for us and Wales' (politician, NI) with potential to kickstart a wider conversation about the roles of the various tiers of government. In the field of social security specifically, about half the civil servants and a small number of politicians viewed Scotland's new competences, and any future divergence as it makes use of them, as an example for Northern Ireland. For many of these interviewees, Northern Irish policy would not be freely chosen by the Assembly, but 'signed off (civil servant, NI) by the UK government. From this perspective, the Smith proposals had potential to shape outcomes and perhaps a 'different form of parity' (civil servant, NI) - if power to make a particular tweak to universal credit is offered to Scotland, the likelihood must increase that a similar change 'might be part of the package' (civil servant, NI) in Northern Ireland. One politician, frustrated at others' perceived reluctance to diverge from the 2012 Act, spoke approvingly of Scotland's early attempts to 'alleviate the burden on people' despite limited powers, notably its use of discretionary housing payments to negate the financial impact of the 'bedroom tax'. With deferral of the social sector size criteria central to Northern Ireland's proposed 'mitigations', this might be viewed as the most direct example of social security policy learning from Scotland.

Although many parallels exist between proposals for divergence in Northern Ireland and new powers in Scotland, the two are not mirror images. Further, 
dissatisfaction with the common UK policy emerges from different environments. Both are devolved regions of the UK and have governments composed at least in part of nationalist/secessionist parties. However, the structure of government differs. While the Scottish government has only ever been composed of one or two parties, Northern Ireland's coalition of up to five parties obstructs the development of a distinctive regional approach in any policy field as its ideologically divergent members seek a 'lowest common denominator' (Gray and Birrell, 2012). Whereas Scottish politics are frequently characterised as ideologically to the left of the UK as a whole, those of Northern Ireland are seen to be dominated by questions of ethno-religious identity (Greer, 2005; McEwen, 2005) within a socially conservative ideological landscape (Racioppi and O'Sullivan See, 2001; Deiana, 2013). These perspectives were reflected in the findings. Although Scottish interviewees did not wish to 'overstate' (politician, Scotland) ideological differences with England, a distinctive philosophy of social citizenship could be identified. While this did not diverge fundamentally from the UK government's construction of paid employment as the 'best route out of poverty' (Child Poverty Unit, 2009: 12), it was believed that a Scottish approach would afford higher priority to 'fair work' paid at a 'living wage' (numerous Scottish interviewees) with less punitive treatment of claimants. In Northern Ireland, it was suggested that the dominance of the parity convention in social security and of the national question in party politics has meant the polity has 'never given much thought ... as to what they believe social welfare should fulfil' (civil servant, NI). Although the 2012 Act had forced engagement with the issue, the fragmented nature of politics was seen as a barrier to the development of 'a political vision for the future for Northern Ireland' (civil servant, NI). Nonetheless, a regional ideology of welfare could be detected, again dominated by the workerist view, more open to the use of 'some kind of stick' or 'cutting back on benefits' (civil servants, NI) to motivate claimants who 'don't want to work' (politician, $\mathrm{NI}$ ), but concerned that policy in Great Britain has become excessively harsh.

Pragmatic as well as ideological explanations for the unsuitability of coalition policy were advanced, notably in connection with the social sector size criteria and personal independence payment. Again, differences in perspective were apparent. While the 'bedroom tax' was portrayed as ill-suited to both regions due to lack of smaller units, reflecting Gibb (2013), several Scottish interviewees referred to a distinctive philosophy of social housing as 'permanent homes' with, in contrast to England, 'no real stigma... about renting your house' (politician, Scotland). Those in Northern Ireland highlighted the region's ethno-religious residential segregation, arguing that no one should be expected to move to smaller accommodation if that meant moving to an area where they might face intimidation (see Gray et al., 2009). Similarly, while interviewees noted high levels of disability in both regions - a key reason for the high projected economic impact of welfare reform in Northern Ireland (Beatty and Fothergill, 2013) - 
those in Northern Ireland saw this as a legacy of political conflict from the 1960s, those in Scotland as an issue for any ex-industrial area. So even where similar conclusions were reached - as on non-implementation of the 'bedroom tax' these may reflect region-specific considerations as well as learning from the other jurisdiction (see Dolowitz and Marsh, 2000).

Policy learning can be top-down as well as horizontal - often 'the clearest path of transfer is from the central government outwards,' frequently as a result of 'financial inducements' (Dolowitz, 2012: 344). In Northern Ireland, where Birrell (2012) highlights failure to draw lessons from Scotland and Wales in important policy decisions, social security policymaking has historically been an example of particularly direct, finance-driven policy transfer from Westminster. Resolution of the region's welfare reform impasse through the temporary transfer of powers to Westminster will allow the extension not only of most of the Welfare Reform Act 2012 but of the social security provisions of the Welfare Reform and Work Bill to the region. This step was taken in the face of (Ministers claimed) overwhelming financial pressures (Hamilton, 2015), enabling 'coercive transfer' of policy (Keating et al., 2012: 292) despite formal devolution of competence and concerns about the policies being imported. Literature on devolution in Spain suggests the funding of a specific devolved service through ring-fenced grants from central government greatly constrains policy autonomy in practice (Subirats and Gallego, 2002). Northern Ireland's weak fiscal position (per capita revenues in 2012-13 were 23 per cent below the UK average and expenditure in 2013-14 was 23 per cent above average - Adam and Miller, 2013; Keep, 2015) means it is heavily dependent on parity transfers and susceptible to pressure to conform to UK government policy. While interview data and parliamentary debates demonstrate that the merits of the Great Britain model are less readily accepted than in the past, finance is presented as the primary obstacle to divergence. Media coverage of the 'welfare reform crisis' frequently focused on the erroneously named 'fines' (Boland, 2015) that would be incurred due to non-replication of the 2012 reforms as the extra costs of an unreformed policy were recovered by the Treasury. Most interviewees in Northern Ireland agreed that it is no more able today to fund its own social protection outside the parity arrangement than in 1926 . So while a civil servant's belief that but for the 'financial issue' there would be no 'appetite for the Westminster solutions' appeared well founded, the 'financial issue' remains at the heart of social security policymaking.

Scotland's finances are healthier: per capita tax take was the highest in the UK in 2012-13 after North Sea revenues are taken into account and only 2.7 per cent below average excluding this income, with expenditure the following year 15 per cent higher than average. However, while the Treasury may be less able to keep Scottish policymakers in a 'straitjacket' (civil servant, Scotland), a clear top-down driver of conformity with UK government policy will continue to exist given that much of social security policy will remain under Westminster 
control; fields to be devolved account for just 25 per cent of non-pension spending (HMG, 2015). Where competence is devolved, the claim of some civil servants (reflecting views expressed at 'After the referendum', 2015) that a distinctive 'Scottish model' of policy development exists, based on close engagement with Scottish stakeholders, might imply a degree of insulation from external influence. Nonetheless fiscal considerations might still constrain capacity to diverge. More optimistic interviewees pointed to the mitigation of the 'bedroom tax' as evidence that Scotland is better placed to absorb the impact of divergence, albeit that the $\mathfrak{E}_{55}$ million which Holyrood spent in $2014-15$ is less than half the annual amount allocated to mitigations by Stormont from 2016 (Berry, 2014; NIO, 2015). Claims from politicians that the abolition of the size criteria (instead of its mitigation) would allow this expenditure to be avoided and that there would be 'more money in the pot' if disability living allowance remained in place up to the point of devolution, rather than being replaced by personal independence payment, appear unrealistic: under the 'no detriment' principle the UK government will not pay for costlier services in Scotland than it provides in England. For those who recognised this, a key strategy for finding the extra money often appeared to be the belief that a fiscally autonomous Scotland, 'no longer... shackled by Westminster policies' (civil servant, Scotland) would inevitably experience accelerated economic growth and increased revenues. Sceptics argued that even if the 'yes' campaign had hinted that an independent Scotland might offer more generous social security, 'at no point did they suggest that it was possible to have a higher budget' (politician, Scotland) and that, in the context of full fiscal autonomy, falls in oil prices would have rendered even maintenance of current benefit levels challenging.

\section{Welfare reform and welfare nationalism}

If responsibility for citizens' economic welfare is a hallmark of the nation state (McLean et al., 2013), it follows that those who claim the status of 'nation' for their sub-state region should aspire to devolved control of the necessary policy fields. Social policy divergence since 1998 has at times been associated with a 'welfare nationalist' project to emphasise solidarity at regional, rather than national, level (Mooney and Poole, 2004). The prominence of secessionist parties in the drive for new devolved social security competences and divergence from UK government policy raises the possibility that this process may be a manifestation of welfare nationalism whose purpose is as much to weaken the social and political unions as to devise a better regional policy.

Welfare unionism and nationalism have a complicated history in Northern Ireland, the UK's 'most intractable territorial problem' (Carmichael, 1996: 413). While social security parity has been explicitly linked with unionism (Lundy, 1996), unionist parties have also driven social policy divergence (Gosling, 2008; 
Thomson, 2013). Interviewees there made little attempt to portray positions on the maintenance of parity as shaped by national aspirations. Politicians tended to present themselves as committed devolutionists and seemed willing to accept the same of their opponents. Civil servants, although convinced of parity's financial importance and universally cautious regarding divergence, also argued (although not unanimously) that the ability to 'tweak' UK government policy is advantageous. Nonetheless, the perspective of unionists and nationalists as to how far parity might be pushed tended to differ. Even if not 'ideologically wedded' to the convention, unionists tended to consider it 'naïve' to suggest the region could be 'exempted' from processes taking place in all other UK regions, or to believe that social security, even if to some extent 'tailored for Northern Ireland,' should 'by and large' mirror Great Britain (politicians, Northern Ireland). This reflects the approach of the Democratic Unionist Party, the largest in the Assembly, which has opposed successive Welfare Reform Bills at Westminster while remaining hesitant about endorsing divergence at Stormont. Nationalists tended to advocate greater divergence: one politician thought it disingenuous to stress the opportunities that devolved competence allows while having a 'cowering attitude' towards confrontation with central government. Nationalists were similarly accused of disingenuity, some unionists and civil servants claiming Sinn Féin's advocacy of divergence was shaped less by the best interests of Northern Ireland than by desire for consistency with an oppositional, anti-austerity platform in the Republic of Ireland.

The view that positions on social security devolution and divergence are 'bound up with the politics and aspirations of independence' (civil servant, Scotland) was more openly expressed in Scotland - usually as a means of criticising political opponents. Hence for one unionist politician, 'the SNP, although I'm sure they do sympathise with better welfare benefits... they're always just an argument... to further independence.' Another criticised the Scottish government's initial prevarication around mitigation of the 'bedroom tax' because (it was claimed) Ministers thought they could gain more politically by 'weaponising' the issue in the independence debate than by 'protect[ing] the Scottish people'. That key aspects of social security were considered by unionists to be 'intrinsic to the make-up of the social union' (politician, Scotland), and therefore unsuitable for devolution, was common ground. This position was criticised on the basis that 'there's a whole host of areas where ... social provision is not the same in different parts of the UK,' and therefore no objective reason why uniformity in social security must be maintained. Unionism could hence be an obstacle to a 'fairer' approach. One politician, who warned any break-up of 'intertwined' taxation and welfare structures must result in the emergence of 'contradictions and tensions' whose outcome for the union could not be predicted, appeared wary of lending ammunition to this argument. Despite these misgivings, this interviewee expressed willingness to 'actually use the powers 
that are coming ... that could actually erode the constitutional settlement' if this meant better outcomes for people in Scotland.

\section{The way ahead: an enduring settlement?}

The command paper on the future of devolution after the referendum purports to provide a blueprint for An enduring settlement for Scotland within the union. Subsequent developments suggest this is unlikely to be the case. The 2015 Labour manifesto advocated additional devolved powers 'over tax, welfare and jobs' (Labour Party, 2015: 65), while even Conservative voices (BBC News, 2015) lend weight to the view that 'we're in flux at the moment and we still have to find a stable solution' (politician, Scotland). In Northern Ireland, despite the temporary transfer of power to Westminster, the 2015 Order is not an exact replica of the 2012 Act and further mitigations will follow (NIO, 2015); how firmly parity has been reinstated remains to be seen.

Findings were in keeping with the view that 'the campaign that happened before the [referendum] continues after it' (politician, Scotland). Interviewees variously criticised Scotland's proposed new powers as insufficient, noted the devolved government's dissatisfaction with An enduring settlement (Scottish Government, 2015) or mocked its title. In the medium term, most Scottish interviewees (including some unionists) aspired to the devolution of additional social security powers. Out-of-work benefits were top of the wish-list, being thought necessary to improve 'outcomes for people who are in receipt of these benefits' (civil servant, Scotland) and to pursue the Scottish government's objectives of a strong economy and social justice. Dissenters highlighted the merits of 'pool[ing] your resources' (politician, Scotland) against social risk across the UK's larger economic base, necessitating pooled decision making. Nor was more radical change necessarily thought to be off the agenda. A Northern Irish politician thought if 'devo max . . . doesn't work I think Scots may well call a referendum sooner rather than later and the yes vote will win.' In Scotland itself, some nationalist politicians similarly saw future prospects for independence as more dependent on the ability of the 'UK establishment' to adapt to the rise of the politics of regionalism than on events in Scotland itself.

The question of whether and how Northern Ireland will move on from the parity convention is complicated by a lack of consensus among interviewees as to how the convention has actually functioned. A number noted that the key question of whether the subvention since 1926 facilitates or requires equivalence of provision with Great Britain - whether the region engages in voluntary policy transfer 'driven by [the] perceived necessity' of its precarious finances or is subject to 'direct imposition' of UK government policy (Dolowitz and Marsh, 2000: 13) - has never been definitively answered. If the extent to which Northern Ireland must ape every aspect of UK government social security policy can be 
questioned, the core principle 'that an individual here... should receive the same level of benefit, subject to the same conditions, as an individual elsewhere in the UK' (McCausland, 2013: 2) was not seriously tested in the political arena before the current period. Even if parity has moved from near-uniformity to a situation in which 'you can do whatever tweaks you so desire provided that (a) you can pay for them and (b) you can operationally deliver them' (civil servant, NI), financial curbs on autonomy should not be underestimated. Further social security cuts (HM Treasury, 2015) will further reduce the expenditure the Treasury will directly fund in Northern Ireland and would therefore increase the cost to the regional budget of an unreformed system. The Welfare Reform and Work Bill may therefore have pushed the regional parties towards agreement on a reform package that will largely bring Northern Ireland back into line with Great Britain. Whether social security 'becomes a sort of running political issue in the north' (civil servant, Scotland) may not be truly tested until the Assembly considers Westminster's next set of reforms. As the Treasury will no more subsidise costlier provision in Scotland than in Northern Ireland, debates as to which innovations are affordable may equally become a feature of the Scottish landscape.

Looking ahead, many interviewees expressed desire for closer intergovernmental relationships, including greater sharing of 'knowledge and experience of what different approaches are being tried' at different tiers and in different regions (politician, Scotland). Some Scottish interviewees felt the dilution of the parity convention in Northern Ireland and partial devolution of competence to Scotland mean social security is no longer reserved or devolved, it's a shared set of responsibilities across the governments' (civil servant, Scotland). Whereas those in Northern Ireland were more likely to foresee continued dominance of the centre, one politician there suggested this meant the devolved regions should aim to play a 'meaningful role' from the earliest stages of UK government policy development. With Spicker's (2015) warning of the potential for conflict between tiers of government, as the Smith recommendations on social security devolution are implemented, reflected in some interviewees' description of relations, it is unsurprising that a Scottish civil servant thought a new era of intergovernmental working would require 'a big cultural change . . . in Whitehall in particular.' Whether anything resembling a partnership of equals is feasible when the UK government holds the purse strings, which is likely to remain the case in Northern Ireland at least, can be questioned.

\section{Conclusion}

Although the UK was never marked by an absolute uniformity of social policy across its component regions, devolution in 1998 has unquestionably changed the character of the social union. The major exception has been social security 
but here, too, change has been in the air since 2012. The UK government's pursuit of controversial reforms, at a time when the forthcoming Scottish referendum meant the advantages of the union were already under scrutiny, has catalysed both the pursuit of new competences in Scotland and an unprecedented challenge to the parity convention in Northern Ireland. Significant regional differences in social protection, therefore, have seemed a realistic prospect as never before.

Devolved governments do not exist in a vacuum; the contemporaneous emergence of challenges to a common UK social security policy in Scotland and Northern Ireland, and the similarities between the divergences proposed in Northern Ireland and the new powers to be devolved to Scotland, suggest a degree of policy learning. Interviewees in Northern Ireland were certainly receptive to this point of view, many arguing that proposed deviations from UK government policy there had influenced the proposed division of social security competences for Scotland, a slightly smaller number suggesting learning had occurred in the opposite direction. Scottish interviewees were undoubtedly eager to learn from Northern Ireland's experience of social security devolution but, rather than wishing to imitate their near neighbour, tended to see it as a warning that formal devolved competences do not always deliver policy autonomy in practice - a situation they were eager to avoid. The true extent of Northern Irish influence may only be revealed through further research as Scotland begins to exercise its new competences. The ultimately limited extent of divergence in Northern Ireland emphasises the continued potential for top-down policy transfer in devolved fields, even when misgivings exist about the UK government agenda. Although Scottish interviewees were, for the most part, confident that their region would be better placed to resist such pressures, such claims cannot really be tested before implementation of the Scotland Act. Whether the messy end to Northern Ireland's welfare reform saga is indicative of a reassertion of the parity convention on the basis of financial necessity, or a temporary truce until the next major reform from Westminster, can only be guessed at present. Ultimately, the fact that Scotland in 2012 and Northern Ireland in 2016 found space for some regional 'mitigations' to policy largely shaped by the UK government shows that in practice it can be difficult to definitively characterise a field of policy as a straightforward example of either divergence or convergence.

Despite the role played by secessionist parties in voicing discontent with UK government policy, interviewees' depictions of the role of 'welfare nationalism' differed significantly. In Scotland, a sharp divide emerged among political interviewees, who either accused nationalists of fanning flames of discontent with the 'welfare reform' agenda in order to generate support for independence, or claimed unionists' obsession with maintaining the social and political unions meant adherence to a set of policies contrary to the interests of citizens. Such debates are likely to be reprised in future calls for devolved social security competences additional to those proposed in an 'enduring' settlement that few 
thought likely to endure long. That policy preferences could be shaped by positions on the national question was also acknowledged in Northern Ireland, but here interviewees were less eager to accuse opponents of allowing their approach to be determined thus, even if there was a clear unionist-nationalist divide as to how extensively the region might diverge from Great Britain. Here, more clearly than in Scotland, aspirations to genuine autonomy in social security are likely to continue to be tempered by fiscal dependence on the Treasury. The social union remains in a state of flux and the ultimate outworkings of the forces unleashed in 2012 will only gradually become clear.

\section{Acknowledgements}

Research conducted under the supervision of Gráinne McKeever (School of Law) and Ann Marie Gray (School of Criminology, Politics and Social Policy) at Ulster University, with the support of a DEL PhD studentship and a PhD fieldwork grant from the Socio-Legal Studies Association. Earlier versions were presented (as 'Social citizenship in the devolutionary state: a clash of law and politics?') at the Socio-Legal Studies Association and (as 'Devolved perspectives on the UK government's welfare reform agenda: parallel or intertwined journeys?') Social Policy Association annual conferences, 2015. Thanks to Ciara Fitzpatrick (Ulster) and the journal's anonymous reviewers for their useful comments.

\section{References}

Adam, S. and Miller, H. (2013), 'Tax revenue in England, Scotland, Wales and Northern Ireland'. London: IFS, $2013<$ http://www.ifs.org.uk/publications/6881>accessed 25 January 2016

'After the referendum: the future for Scottish social policy' (Social Policy Association seminar, University of Strathclyde, Glasgow, February 2015)

Arriba, A. and Moreno, L. (2005), 'Spain - poverty, social exclusion and 'safety nets', Ferrera, M. (ed), Welfare state reform in southern Europe: fighting poverty and social exclusion in Italy, Spain, Portugal and Greece. London: Routledge

BBC News. (2015), 'Cameron will “look at” proposals for further Scottish devolution', BBCNews, 15 May <http://www.bbc.co.uk/news/uk-scotland-scotland-politics-32746049>accessed 25 January 2016

Beatty, C. and Fothergill, S. (2013), The impact of welfare reform on Northern Ireland. Sheffield: Centre for Economic Empowerment

Berry, K. (2014), Discretionary housing payments. (SPICe 14/17). Edinburgh: Scottish Parliament Birrell, D. (2009), The impact of devolution on social policy. Bristol: Policy Press

Birrell, D. (2010), 'Devolution and approaches to social policy', G. Lodge and K. Schmueker. (eds), Devolution in practice 2010. London: IPPR

Birrell, D. (2012), 'Policy copying and public sector reform in Northern Ireland' Regional and Federal Studies, 22(3), 309-321

Birrell, D. and Gray, A.M. (2014), 'Welfare reform and devolution: issues of parity, discretion and divergence for the UK government and the devolved administrations', Public Money and Management, 34:3, 205-212

Boland, V. (2015), 'Stakes high in Northern Ireland welfare reform crisis', Financial Times 27 May <http://www.ft.com/cms/s/o/1172b9c8-0478-11e5-a5c3-00144feabdco.html>accessed 25 January 2015

Carmichael, P. (1996), 'The changing territorial operating code of the United Kingdom: evidence from Northern Ireland' Public Administration, 74:3 413-433

Charmaz, K. (2006), Constructing grounded theory: a practical guide through qualitative analysis. London: Sage 
Child Poverty Unit. (2009), Ending child poverty: making it happen. London: HM Government

Clegg, D. (2014), 'David Cameron, Ed Miliband and Nick Clegg sign joint historic promise which guarantees more devolved powers for Scotland and protection of NHS if we vote No', Daily Record, 15 September < http://www.dailyrecord.co.uk/news/politics/ david-cameron-ed-miliband-nick-4265992>accessed 25 January 2016

Commission on Scottish Devolution. (2009), Serving Scotland better: Scotland and the United Kingdom in the 21st century. Edinburgh: Commission on Scottish Devolution

Committee for Social Development. (2013), Report on the Welfare Reform Bill (NIA Bill 13/11-15). (NIA 74/11-15). Belfast: Northern Ireland Assembly

Craig, J, Hansard: HC Deb. (NI). (1925) vol 6 col 468

Curtice, J. and Ormston, R. (2011), 'Is Scotland more left-wing than England?' Edinburgh: ScotCen Social Research

Deiana, M-A. (2013), 'Women's citizenship in Northern Ireland after the 1998 Agreement' Irish Political Studies 28:3, 399-412

Department for Social Development. (2013), Resource accounts for the year ended 31 March 2013 Belfast: DSD, 2013

Dolowitz, D. (2012), 'Conclusion: what have we learned?' Regional and Federal Studies 22(3), $341-351$

Dolowitz, D., Greenwold, S. and Marsh, D. (1999), 'Policy transfer: something old, something new, something borrowed, but why red, white and blue?' Parliamentary Affairs 52(4), $719-730$

Dolowitz, D. and Marsh, D. (2000), 'Learning from abroad: the role of policy transfer in contemporary policy-making' Governance 13(1), 5-24

Expert Working Group on Welfare. (2014), Re-thinking welfare: fair, personal and simple Edinburgh: Scottish Government

Faist, T. (2001), 'Social citizenship in the European Union: nested membership' Journal of Common Market Studies 39:1, 37-58

Gibb, K. (2013), The 'bedroom tax' in Scotland. (SP 409). Edinburgh: Scottish Parliament

Glaser, B.G. and Strauss, A.L. (1967), The discovery of grounded theory: strategies for qualitative research New York: Aldine

Gosling, P. (2008), 'Northern Ireland locked in schools stalemate', Public Finance 23 May, $14-15$

Government of Wales Act 2006 c32

Gray, A.M. and Birrell, D. (2012), 'Coalition government in Northern Ireland: social policy and the lowest common denominator thesis', Social Policy and Society 11:1, 15-25

Gray, P., McAnulty, U. and Keenan, M. (2009), 'Moving towards integrated communities in Northern Ireland: new approaches to mixed housing', European Journal of Housing Policy 9:3, 337-353

Greer, S.L. (2005), 'The territorial bases of health policymaking in the UK after devolution', Regional and Federal Studies 15:4, 501-518

Hamilton, S. (2015), 'Welfare reform madness will cost us millions we just haven't got', Belfast Telegraph, 12 March <http://www.belfasttelegraph.co.uk/opinion/debateni/ simon-hamilton-welfare-reform-madness-will-cost-us-millions-we-just-havent-got31060139.html>accessed 25 January 2016

Hansard: NIA deb (26 May 2015) vol 105 no 1 p1

Harris, N. (2013), Law in a complex state: complexity in the law and structure of welfare. Oxford: Hart

Harris, N. (2014), 'Welfare reform and the shifting threshold of support for disabled people', Modern Law Review 77:7, 888-927

Henderson, A., Jeffery, C., Wincott, D. and Wyn Jones, R. (2013), 'Reflections on the "devolution paradox": a comparative example of multilevel citizenship', Regional Studies 47:3, 303-322

HM Government (2015), Scotland in the United Kingdom: an enduring settlement. (Cm 8990), Edinburgh: Scotland Office 
HM Revenue and Customs (2013), Northern Ireland national insurance fund account for the year ended 31 March 2013. (HC 894). London: TSO

HM Treasury (2015), Summer budget 2015. (HC 264). London: HM Treasury

Hombrado Martos, A. (2008), 'Institutionally induced autonomy: the case of Andalusia'. Northern PSA Postgraduate Conference, Edinburgh

Keating, M. (2009), 'Social citizenship, solidarity and welfare in regionalised and plurinational states', Citizenship Studies, 13:5, 501-513

Keating, M. and Cairney, P. (2012), 'Introduction: policy-making, learning and devolution', Regional and Federal Studies, 22:3, 239-250

Keating, M., Cairney, P. and Hepburn, E. (2012), 'Policy convergence, transfer and learning in the UK under devolution', Regional and Federal Studies, 22:3, 289-307

Keep, M. (2015), 'Public expenditure by country and region'. (SN/EP/4033). London: House of Commons Library

Labour Party (2015), Britain can be better: the Labour Party manifesto 2015. London: Labour Party

Larkin, P.M. (2011), 'The legislative arrival and future of workfare: the Welfare Reform Act 2009' Journal of Social Security Law 18:1, 11-32

Lawrence, R.J. (1965), The government of Northern Ireland: public finance and public services 1921-1964. Oxford: Clarendon Press

Lodge, G. and Trench, A. (2014), Devo more and welfare: devolving benefits and policy for a stronger union. London: IPPR

Lundy, L. (1996), 'Parity, parrotry or plagiarism? Legislating for the unemployed poor in Northern Ireland 1838-1995', N Dawson, D Greer and P Ingram. (eds), One hundred and fifty years of Irish law, Belfast: SLS Legal Publications

McCausland, N. in Committee for Social Development (2013), Welfare Reform Bill: Ministerial briefing. (Official Report). NIA 31 January

McEwen, N. (2005), 'The territorial politics of social policy development in multilevel states', Regional and Federal Studies 15:4, 537-554

McLean, I., Gallagher, J. and Lodge, G. (2013), Scotland's choices: the referendum and what happens afterwards. Edinburgh: Edinburgh University Press

Mitchell, J. (2014), The Scottish question. Oxford: Oxford University Press

Mooney, G. and Poole, L. (2004), "'A land of milk and honey"? Social policy in Scotland after devolution', Critical Social Policy 24:4, 458-483

Mooney, G. and Scott, G. (2015), 'The 2014 Scottish independence debate: questions of social welfare and social justice', Journal of Poverty and Social Justice 23:1, 5-16

Mooney, G and Williams, C. (2006), 'Forging new "ways of life"? Social policy and nation building in devolved Scotland and Wales', Critical Social Policy 26:3, 608-629

Northern Ireland Act 1998 c47

Northern Ireland (Welfare Reform) Act 2015 c34

Northern Ireland Office (2014), The Stormont House Agreement Belfast: NIO

Northern Ireland Office (2015), A fresh start: the Stormont agreement and implementation plan Belfast: NIO

Racioppi, L. and O'Sullivan See, K. (2001), “This we will maintain”: gender, ethno-nationalism and the politics of unionism in Northern Ireland', Nations and Nationalism, 7:1 93-112

Rose, R. (2000), 'What can we learn from Abroad?' Parliamentary Affairs 53, 628-643

Scotland Act 1998 c46

Scotland Act $2016 \mathrm{c11}$

Scotland HC Bill (2015-16) [3]

Scotland Office (2009), Scotland's future in the United Kingdom: building on ten years of Scottish devolution. (Cm 7738). Edinburgh: Scotland Office

Scottish Government (2015), 'Smith clauses give Westminster veto in key areas'. Press release, 22 January <http://news.scotland.gov.uk/News/Smith-clauses-give-Westminsterveto-in-key-areas-14d 4 .aspx $>$ accessed 25 January 2016 
Scottish National Party. (2013), 'UK's catastrophic welfare changes set to bite'. Press release, 1 April <http://www.snp.org/media-centre/news/2013/apr/uks-catastrophicwelfare-changes-set-bite $>$ accessed 17 February 2014

Simpson, M. (2015), 'Developing constitutional principles through firefighting: social security parity in Northern Ireland', Journal of Social Security Law 22:1, 31-49

Smith Commission. (2014), Report of the Smith Commission for further devolution of powers to the Scottish Parliament. Edinburgh: Smith Commission

Social Security Advisory Committee. (2015), 'Localisation and social security: a review'. (occasional paper 14). London: SSAC

Spicker, P. (2015), 'The devolution of social security benefits in Scotland: the Smith Commission' Journal of Poverty and Social Justice 23:1, 17-28

Stephens, T. (2015), 'Income-replacement benefits, child benefit and inflation, 1992-2015'. London: Child Poverty Action Group

Storey, M. (2014), Letter to NI church leaders, 20 October 2014. <http://www.irishchurches. $\mathrm{org} / \mathrm{blog} / 2014 / 10 /$ welfare-reform-response-from-minister-mervyn-storey/>accessed 25 January 2016

Subirats, J. and Gallego, R. (2002), 'El análisis del rendimiento institucional: teoría y aplicacíon a los comunidades autónomas', J Subirats and R Gallego. (eds), Veinte años de autonomías en España: leyes, políticas públicas, instituciones y opinión pública. Madrid: Centro de Investigaciones Sociológicas

Thomson, J. (2013), 'Abortion politics in Northern Ireland: breaking the political divide?' Political Studies Association, 10 September <https://www.psa.ac.uk/psacommunities/specialist-groups/irish-politics-group/blog/abortion-politics-northernireland-o $>$ accessed 25 January 2016

Welfare Reform Act 2012 C5

Welfare Reform Mitigations Working Group. (2016), Welfare Reform Mitigations Working Group Report. Belfast: OFMDFM

Welfare Reform Bill (NIA Bill 13/11-15)

Welfare Reform (Northern Ireland) Order 2015 no 2006

Wincott, D. (2006), 'Social citizenship and social policy: Britain's welfare states', Publius 36:1, 169-188 